\title{
Blood metabolites and fecal starch as indicators of feed efficiency of beef cattle in the feedlot
}

\author{
[Metabolitos sanguíneos e amido fecal como indicadores da eficiência alimentar do gado de
} corte em confinamento]

\author{
A. Fornazari Neto ${ }^{1}$, C.E.N. Martins ${ }^{1}$ (D) , E. Schwegler ${ }^{1}$ (D) J.O.J. Barcellos ${ }^{2}$ (D) A.L. Barth ${ }^{3}$ (D) \\ ${ }^{1}$ Instituto Federal de Santa Catarina, Araquari, SC, Brasil \\ ${ }^{2}$ Universidade Federal do Rio Grande do Sul, Porto Alegre, RS, Brasil \\ ${ }^{3}$ Undergraduate, Instituto Federal de Santa Catarina, Araquari, SC, Brasil
}

\begin{abstract}
The use of blood metabolites (BM), fecal starch (FS), and apparent digestion of starch, (ATTSD) as indicators of feed efficiency (FE) in beef cattle in the feedlot was studied. Fourteen bulls were used, originating in an industrial cross, without a defined racial group, with mean body weight of $284.86 \mathrm{~kg}$, individually fed, being evaluated in a 42-day confinement system. After the evaluation, the animals were divided into two groups according to the individual FE: high feed efficiency (HE) and low feed efficiency (LE). There was a difference between the groups in the variables FE, feed conversion (FC), final weight (FW), and daily weight gain (DWG). The FE had a positive correlation with DWG, FC, and FW. There was no difference between the groups for the variables BM, FS, and ATTSD, nor was there any correlation between these variables and FE. Considering the feed cost, the HE animals proved more profitable. BM, FS, and ATTSD did not statistically show potential to be used as indicators of FE, despite the evidence of numerical differences of these variables between the different groups, tendency of correlations with FE, and discriminating function with potential assertiveness.
\end{abstract}

Keywords: animal nutrition, feed efficiency, blood metabolites, fecal starch, feedlot of beef cattle

\section{RESUMO}

Foi estudada a utilização dos metabólitos sanguíneos (BM), do amido fecal (FS) e da digestão aparente do amido (ATTSD) como indicadores de eficiência alimentar (FE) em bovinos de corte em confinamento. Utilizaram-se 14 touros, originários de cruzamento industrial, sem grupo racial definido, peso corporal médio de 284,86kg, alimentados individualmente, sendo avaliados em sistema de confinamento por 42 dias. Após a avaliação, dividiram-se os animais em dois grupos, de acordo com a FE individual: alta eficiência alimentar $(H E)$ e baixa eficiência alimentar (LE). Houve diferença entre os grupos nas variáveis $F E$, conversão alimentar $(F C)$, peso final $(F W)$ e ganho de peso diário $(D W G)$. A FE teve correlação positiva com $D W G, F C$ e $F W$. Não houve diferença entre os grupos para as variáveis BM, FS e ATTSD, tampouco houve correlação entre essas variáveis e a FE. Considerando-se o custo alimentar, os animais HE mostraram-se mais lucrativos. BM, FS e ATTSD não mostraram, estatisticamente, potencial para serem utilizados como indicadores de FE, apesar da evidência de diferenças numéricas dessas variáveis entre os diferentes grupos, tendência de correlações com a FE e de função discriminante com potencial assertividade.

Palavras-chave: nutrição animal, eficiência alimentar, metabólitos sanguíneos, amido fecal, confinamento de bovinos de corte

\section{INTRODUCTION}

The termination of beef cattle in a confinement system is a reality implanted in the world's major players of meat production. These farms work with the objectives of producing quality meat and maximizing profitability.
For this, it is necessary to optimize the available resources, with animals and feed, respectively, having the highest production costs (Lopes and Magalhães, 2005; Ferreira et al., 2009).

In the feed, the higher costs are related to energy sources, such as cereals in the form of silages and

Corresponding author: fornazarinetto@hotmail.com

Submitted: March 8, 2021. Accepted July 16, 2021. 
concentrates, the main sources of this nutrient, basically in the form of starch.

Feed efficiency (FE) undergoes large variations between animals, with differences in feed intake, organs size, differences in metabolism, and the digestion and use of food (Herd et al., 2004; Almeida, 2005).

The difference in the metabolization of nutrients in biologically different animals concerning FE may have modifications in blood metabolites levels (BM) (Richardson et al., 2000; Montanholi, 2006; Santana et al., 2014).

Digestion can also diverge between animals with different FE, expressing productive differences, as well as in what is excreted in feces, especially starch (Caetano, 2008; Silva et al., 2012).

This study aimed to verify the possibility of using $\mathrm{BM}$, the rate of digestion of starch in the total digestive tract (ATTSD) and starch excreted in feces - fecal starch (FS) as indicators of FE in beef cattle in the feedlot.

\section{MATERIAL AND METHODS}

The study was carried out in the Joaçaba, Santa Catarina, Brazil $\left(27^{\circ} 09^{\prime} 27.9^{\prime \prime} \mathrm{S} 51^{\circ} 39^{\prime} 05.2^{\prime \prime} \mathrm{W}\right)$, from February to March 2018, with 14 male beef cattle, not castrated, from commercial herds of the industrial crossing of breeds for meat, without specific definition of racial prevalence, with $284.86 \pm 6.72 \mathrm{~kg}$ body weight, approximate age of 12 months. The animals were housed in a covered confinement structure, with a concrete floor, in individual pens of $4 \mathrm{~m}^{2}$, on average. A period of 21 days of adaptation was carried out, gradually introducing the concentrate to the diet. After that, the 42-day trial period began, where daily feeding was provided (Table 1), divided into two meals, in a balanced manner according to parameters of the National Research Council - Nutrient Requirement of Beef Cattle for high gain performance (NRC, 2000). The concentrated feed and the forage were supplied individually, in the same trough, without mixing them, in a high ratio concentrate:forage $(80: 20)$, controlling the individual food intake through the weighing of the food supplied and the respective leftovers.
The Near Infrared Spectroscopy (NIRS) method was used for the bromatological analysis of food, using Foss equipment, Foss 5000 model for forage analysis (Tifton hay cv. 85) and concentrate starch. For concentrate analysis, the Perten equipment, model DA7250, was used.

The formulation of concentrate, levels of the chemical composition of the concentrate, and the forage, and their quantities can be observed in Table 1.

The animals were weighed at the beginning and the end of the experimental period, always at specific times and fasting solids for 12 hours. The animals were weighed at the beginning and at the end of the experimental period, always at specific times and fasting solids for 12 hours.

At the end of the 42 days of the experiment, after final weighing, blood and feces samples were collected and calculated:

DMI = (total food provided - total food leftovers $)$ / experiment days;

DWG = (final body weight - initial body weight $)$

/ experiment days;

$\mathrm{FC}=\mathrm{DMI} / \mathrm{DWG}$

$\mathrm{FE}=\mathrm{DWG} / \mathrm{DMI}$

For blood collection, the animals presented fasting of solids of 14 hours, and venous blood samples were collected by puncture of the jugular vein in tubes without anticoagulant, with EDTA $(10 \%)$ and a tube with glycolytic pathway inhibitor. After collection, the tubes with the samples without anticoagulant were centrifuged at $1800 \mathrm{~g}$ for 15 minutes and the serum was deposited in Eppendorf tubes and packed at -20 ${ }^{\circ} \mathrm{C}$ for subsequent biochemical analyses. In the BM biochemical analyses were performed by colorimetric methods. Albumin and Urea (blood serum, Labtest, Labtest Specific Reagents, colorimetric method); Glucose (blood serum, Bioplus, Bioplus Bio-200, kinetic biochemical method by automation); Cholesterol (blood serum, Bioplus, Bioplus Bio-200, enzymatic colorimetric method); Blood count (whole blood with EDTA, Sysmex, Sysmex pocH+100iV Diff, being: Erythrocytes, impedance method and hydrodynamic focus; Leukocytes, impedance method; Hemoglobin, cyanide-free method; Hematocrit, cumulative pulse height method). 
Table 1. Ingredients, chemical composition, and quantity of food supplied to beef cattle in feedlot

\begin{tabular}{|c|c|c|}
\hline Ingredients & \multicolumn{2}{|c|}{ Concentrate (NM) } \\
\hline Corn ground $(\%)$ & \multicolumn{2}{|c|}{62.50} \\
\hline Soybean hulls $(\%)$ & \multicolumn{2}{|c|}{27.50} \\
\hline Soybean meal 45 (solvent) $(\%)$ & \multicolumn{2}{|c|}{5.00} \\
\hline Nucleus mineral $(\%)$ & \multicolumn{2}{|c|}{2.00} \\
\hline Nucleus buffer $(\%)$ & \multicolumn{2}{|c|}{2.00} \\
\hline Livestock urea $(\%)$ & \multicolumn{2}{|c|}{1.00} \\
\hline Nutrients & Concentrate (DM) & Forage (DM) \\
\hline $\mathrm{CP}(\%)$ & 13.77 & 14.42 \\
\hline $\mathrm{EE}(\%)$ & 2.48 & 1.57 \\
\hline $\mathrm{MM}(\%)$ & 5.87 & 6.42 \\
\hline $\operatorname{NDF}(\%)$ & 22.90 & 65.43 \\
\hline Starch $(\%)$ & 44.21 & 0.26 \\
\hline $\mathrm{NFC}(\%)$ & 61.66 & 13.60 \\
\hline NEg (Mcal/kg) & 1.25 & 0.61 \\
\hline Calcium $(\%)$ & 1.82 & 0.13 \\
\hline Phosphorus (\%) & 0.62 & 0.26 \\
\hline Monensin - ppm & 40.00 & - \\
\hline Saccharomyces cerevisiae (CFU/kg) & $2 \times 10^{9}$ & - \\
\hline $\begin{array}{l}\text { Foods } \\
\end{array}$ & & \\
\hline Concentrate (kg DM/day) & & \\
\hline Tifton cv. 85 hay (kg MS/day) & & \\
\hline
\end{tabular}

Samples collected were 250 grams of fresh feces from each animal, immediately refrigerated and after approximately 12 hours, they were dehydrated by heated ventilation and sent for analysis.

In the analysis of feces, it was verified: FS (dehydrated feces, Foss, Foss 5000, NIRS method); ATTSD (fecal starch data applied in equation, 3rlab, equation method adapted from Zinn et al. (2007), being: Starch digestibility, \% = $99.9-(0.413 \times$ FS $)-\left(0.0131 \times \mathrm{FS}^{2}\right)$, where: FS: Fecal starch $\left(\mathrm{R}^{2}=0.96\right)$.

At the end of the experiment, the general average of FE of the total animals were separated into two distinct groups concerning FE, being a group of high feed efficiency (HE) (six animals with HE above the average of the total group) and another group of low feed efficiency (LE) (eight animals with and below the average of the total group). The data were submitted to the tests: ShapiroWilk, correlation analyses, main components, and discriminating, with the help of the statistical software R (R Core Team, 2018). Variance analyses and Tukey's test was carried out in the SPSS statistical software (IBM, 2018), the initial weight being a covariate in the model. The level of significance used for the analyses was $5 \%$.

\section{RESULTS AND DISCUSSION}

The sorting diagram (Figure 1) presents the result of the analysis of the main components, where we observe the distribution of the HE and LE animals on the chart, showing that there is a tendency to separate animals from different FE (HE, left side and LE, right side). Albumin, DMI, haematocrit, haemoglobin, erythrocyte, glucose and ATTSD showed correlation $(\mathrm{P}<0.05)$ of $0.81 ; 0.77 ; 0.76$; $0.75 ; 0.63 ; 0.55$ and -0.54 with component 1 of the ordering diagram respectively. Component 2 correlated $(\mathrm{P}<0.05)$ with erythrocyte $(\mathrm{r}=0.69)$, haemoglobin $(\mathrm{r}=0.54)$, DWG $(\mathrm{r}=-0.6)$ and $\mathrm{FE}$ $(\mathrm{r}=-0.7)$. 


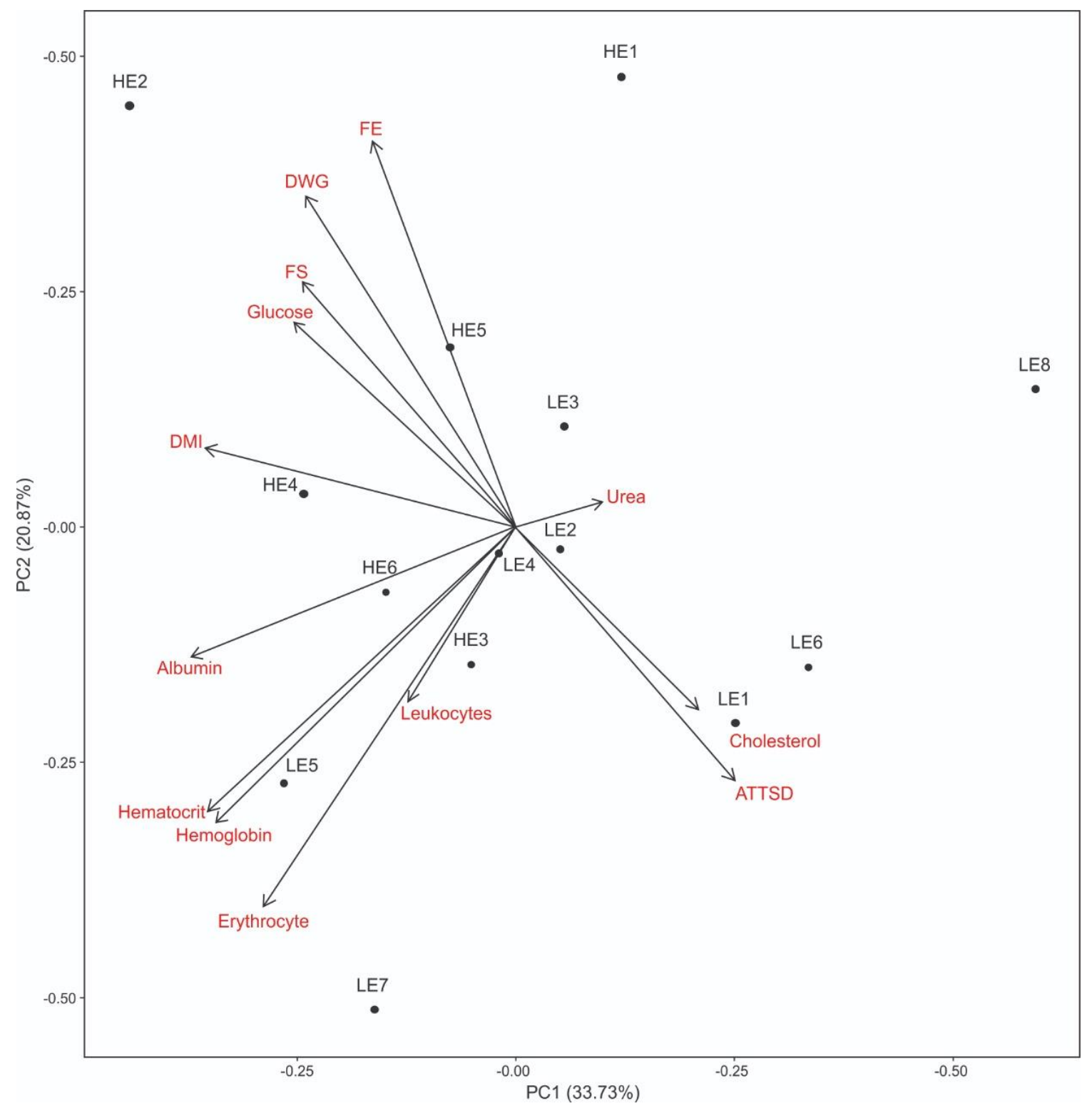

Figure 1. Ordering diagram of performance variables, blood metabolites, fecal starch, and apparent starch digestion in the total digestive tract of beef cattle in the feedlot.

FE: Feed efficiency; DWG: Daily weight gain; FS: Fecal starch; DMI: Dry matter intake; ATTSD: Apparent total tract starch digestibility; HE1 - HE6: high feed efficiency animals; LE1 - LE8: low feed efficiency animals

The final weight variables, daily weight gain, feed conversion, and dry matter consumption presented a correlation of $0.54 ; 0.95 ;-0.98$, and 0.51 with FE, respectively. The same behavior was not observed for blood metabolites (Table 2).
Silva et al. (2012) observed a correlation between FS and DWG $(r=0.36 ; P=0.10)$ and $F S$ and FE $(r=0.48 ; \mathrm{P}<0.05)$. However, in this study, it was found that there was no correlation between FS and FE, information that corroborates the data found by Stella (2010). 
Table 2. Correlation between FE and performance variables, blood metabolites, fecal starch, and apparent total tract starch digestibility of beef cattle in the feedlot

\begin{tabular}{lcc}
\multicolumn{1}{c}{ Variable } & Correlation & Probability \\
\hline Initial weight & 0.160 & 0.586 \\
Final weight & 0.540 & 0.046 \\
Daily weight gain & 0.954 & 0.002 \\
Dry matter intake & 0.514 & 0.060 \\
Feed conversion & -0.983 & 0.003 \\
Erythrocyte & -0.226 & 0.437 \\
Hemoglobin & -0.127 & 0.666 \\
Hematocrit & -0.140 & 0.632 \\
Leukocytes & 0.046 & 0.876 \\
Cholesterol & -0.142 & 0.628 \\
Glucose & 0.319 & 0.267 \\
Albumin & 0.215 & 0.461 \\
Urea & -0.222 & 0.446 \\
Fecal starch & 0.127 & 0.665 \\
ATTSD & -0.154 & 0.600 \\
\hline ATTSD & &
\end{tabular}

ATTSD: Apparent total tract starch digestibility

In Table 3 the existence of differences in FE between animals and between different groups stands out, being FE $0.22 \mathrm{~kg}$ for group $\mathrm{HE}$ and $0.18 \mathrm{~kg}$ for group LE $(\mathrm{P}=0.002)$. Euclides Filho et al. (2001) state that there is a bionutritional difference between different genetic groups.
These distinctions concerning to efficiency may represent economic differences between production systems, and their evaluation is important (Euclides Filho et al., 2003; Santana et al., 2014).

Table 3. Animal performance, blood metabolites, fecal starch, and apparent digestion of starch in the total digestive tract of the high and low feed efficiency of beef cattle in the feedlot

\begin{tabular}{|c|c|c|c|}
\hline \multirow{2}{*}{ Variable } & \multicolumn{2}{|c|}{ Feed efficiency } & \multirow{2}{*}{ Probability } \\
\hline & High & Low & \\
\hline Initial weight (kg BW) & $282.5 \pm 11.69$ & $286.63 \pm 8.53$ & 0.770 \\
\hline Final weight (kg BW) & $365.78 \pm 3.49$ & $346.66 \pm 3.02$ & 0.002 \\
\hline Dry matter intake (kg/day) & $8.72 \pm 0.22$ & $8.12 \pm 0.19$ & 0.070 \\
\hline Daily weight gain (kg/day) & $1.93 \pm 0.08$ & $1.47 \pm 0.07$ & 0.002 \\
\hline Feed efficiency $(\mathrm{kg})$ & $0.22 \pm 0.008$ & $0.18 \pm 0.007$ & 0.002 \\
\hline Feed conversion $(\mathrm{kg})$ & $4.56 \pm 0.20$ & $5.57 \pm 0.17$ & 0.003 \\
\hline Erythrocyte (millions $/ \mathrm{mm}^{3}$ ) & $8.64 \pm 0.67$ & $9.01 \pm 0.58$ & 0.689 \\
\hline Hemoglobin $(\mathrm{g} / \mathrm{dl})$ & $12.62 \pm 0.61$ & $12.67 \pm 0.53$ & 0.952 \\
\hline Hematocrit $(\%)$ & $36.92 \pm 1.94$ & $37.82 \pm 1.68$ & 0.734 \\
\hline Leukocytes (thousand $/ \mathrm{mm}^{3}$ ) & $14.28 \pm 1.47$ & $11.83 \pm 1.27$ & 0.232 \\
\hline Cholesterol (mg/dl) & $88.26 \pm 5.49$ & $98.81 \pm 4.75$ & 0.175 \\
\hline Glucose $(\mathrm{mg} / \mathrm{dl})$ & $88.61 \pm 5.39$ & $85.42 \pm 4.66$ & 0.664 \\
\hline Albumin (mg/dl) & $2.44 \pm 0.11$ & $2.26 \pm 0.10$ & 0.244 \\
\hline Urea $(\mathrm{mg} / \mathrm{dl})$ & $15.76 \pm 2.41$ & $21.38 \pm 2.09$ & 0.107 \\
\hline Fecal starch (\% DM) & $5.57 \pm 0.79$ & $4.13 \pm 0.68$ & 0.197 \\
\hline ATTSD (\% digestion) & $97.06 \pm 0.44$ & $97.92 \pm 0.38$ & 0.174 \\
\hline
\end{tabular}

BW: Body weight; DM: Dry matter; ATTSD: Apparent total tract starch digestibility

The differences in meat production efficiency are related to genetic differences and interactions between genes and environment, causing changes in DMI, organs size and viscera, metabolic differences, especially concerning energy. It is evident that the most efficient animals have lower energy needs for maintenance and produce less heat, thus better-converting energy into weight gain (Almeida, 2005). These data are also corroborated by Basarab et al. (2003). 
Regarding FC, there was a difference of $2.55 \mathrm{~kg}$ between the most efficient animal and the least efficient animal. Between groups HE and LE, the difference between the means was $1.005 \mathrm{~kg}$ $(\mathrm{P}=0.003)$ (Table 3).

The groups also showed differences in the means of the DWG $(\mathrm{P}=0.002)$, and the difference in DWG between the groups was $0.455 \mathrm{~kg}$. There was a positive correlation between FE and DWG $(\mathrm{r}=0.954 ; \mathrm{P}<0.01)$.

Regarding DMI, the data differed from the information found for FE and DWG, where the difference had less consistency as the animals were distributed among the groups. The difference in DMI found between the animals HE and $\mathrm{LE}$ was $0.595 \mathrm{~kg}$ of DMI $/$ day, with higher consumption in the HE group $(8.717 \mathrm{~kg}$ of $\mathrm{DMI} /$ day) and lower in the LE group $(8.122 \mathrm{~kg}$ of $\mathrm{DMI} /$ day $)(\mathrm{P}=0.07)$.

Concerning BM, in the blood cell part of the red series (erythrocytes, hematocrit, and hemoglobin) and white series (leukocytes) no differences were observed.

Other studies (Bourgon et al., 2017; Stieven, 2012) corroborate this, where non-observation of differences for erythrocytes, hematocrit, hemoglobin, and leukocytes, between groups of different FE, are reported when studying residual food intake (RFI).

Statistical differences were found in animal blood variables with $\mathrm{HE}$ and $\mathrm{LE}$, being lower values for hemoglobin $(\mathrm{P}<0.01)$ and hematocrit $(\mathrm{P}<0.01)$, in animals $\mathrm{HE}$, due to possible associations to differences in Oxygen transportation (Richardson et al., 2000).

Cholesterol was the second blood metabolite with a greater numerical difference $(88.256 \mathrm{mg} / \mathrm{dl}$ for animals HE and $98.808 \mathrm{mg} / \mathrm{dl}$ for animals LE), however unto statistical difference $(\mathrm{P}=0.17)$. At work evaluating FE through RFI, they found differences between groups of animals for cholesterol, evidencing lower values in the most efficient animals (2.62 mmol/l) when compared to low-efficiency animals (3.05 $\mathrm{mmol} / \mathrm{l})$, corroborating with the data of the present study (Montanholi et al., 2017).
In the FE study, they found positive cholesterol correlations with DMI $(\mathrm{r}=0.34 ; \mathrm{P}<0.1)$, cholesterol with DWG $(\mathrm{r}=0.43, \mathrm{P} \leq 0.05)$, and cholesterol and FE (RFI) ( $\mathrm{r}=0.21 ; \mathrm{P}>0.1)$, evidencing that cholesterol has potential as a possible indicator of feed efficiency, appearing to be predictive of RFI (Bourgon et al., 2017). The data from Bourgon et al. (2017) differ from the data found in the study, where there were negative correlations between cholesterol and DMI ( $\mathrm{r}=-0.398 ; \mathrm{P}=0.158)$, cholesterol, and $\mathrm{DWG}$ $(\mathrm{r}=-0.256 ; \mathrm{P}=0.376)$ and cholesterol with $\mathrm{FE}$ ( $\mathrm{r}=-0.142 ; \mathrm{P}=0.628)$.

The study showed no statistical difference in blood glucose between groups $\mathrm{HE}$ and $\mathrm{LE}$ $(\mathrm{P}=0.66)$, despite the existence of numerical difference, higher in the HE animals $(88.61 \pm 12.49 \mathrm{mg} / \mathrm{dl})$, corroborating the data found by Montanholi et al. (2017). In working with Purunã bulls, they verified lower glucose values in the HE animals (Fernandes et al., 2014). It was found by other authors that there were no differences between animals with higher or lower FE regarding plasma glucose levels (Bourgon et al., 2017).

Clemmons et al. (2017) in their work evaluating FE in Black Angus steers, claim to have not found differences in glucose levels between the high and low feed efficiency groups. The evidence of the absence of differences in glucose levels among cattle of high and low feed efficiency is possibly explained by the fact that ruminants have a high capacity to regulate blood glucose levels through neoglycogenesis (Young, 1977).

When the metabolite albumin was analyzed, the values did not differ, only presenting numerical difference, with values of $2.44 \mathrm{mg} / \mathrm{dl}$ and $2.26 \mathrm{mg} / \mathrm{dl}(\mathrm{P}=0.244)$, for animals $\mathrm{HE}$ and $\mathrm{LE}$, respectively, similar to that verified by Fernandes et al. (2014).

Unlike the study by Montanholi et al. (2017) where they found higher values $(37.65 \mathrm{mg} / \mathrm{l})$ in less efficient animals and lower values $(36.18 \mathrm{mg} / \mathrm{l})$ in more efficient animals $(\mathrm{P}=0.001)$.

For the metabolite urea, the LE animals presented higher values $(21.38 \mathrm{mg} / \mathrm{dl})$ concerning $\mathrm{HE}$ (15.76mg/dl), $\quad(\mathrm{P}=0.11)$. Hammond (1992) observed in the fattening of steers that the maximum performance was associated with blood 
urea nitrogen concentrations of 7 to $8 \mathrm{mg} / \mathrm{dl}$, numbers that approach and corroborate the observation of animals with $\mathrm{HE}$, after conversion of blood urea values.

These data reinforce the thesis that more efficient animals in feed conversion better convert the feed protein into microbial protein and thus present better performance, associated with lower rates of blood urea.

In similar work, Bourgon et al. (2017) when assessing blood urea, there were no significant numerical differences, being lower for $\mathrm{HE}$ animals $(3.92 \mathrm{mmol} / \mathrm{l})$ and higher for LE animals $(4.12 \mathrm{mmol} / \mathrm{l})$. A negative correlation $(\mathrm{r}=-0.04)$ between blood urea content and HE animals, when evaluated by RFI, corroborating data of the correlation between FE and urea of this study ( $r=-$ 0.22 ).

Equivalence was observed for starch measured in animal feces between the two groups, with slightly higher numerical values of the HE group $(5.57 \%)$, indicating an estimate of a small decline in ATTSD of these animals, $97.06 \%$ for the HE group and $97.92 \%$ for the LE group $(\mathrm{P}=0.17)$. Silva et al. (2012) suggest that the utilization of starch may be related to animal performance. Corona et al. (2006) in their work with the digestion of corn starch, affirm that the digestion and excretion of starch may vary depending on vitreousity and feed processing.

Channon et al. (2004) observed that animals with lower FE digested starch less, due to incomplete digestion of starch in the rumen, small intestine, and large intestine, diverging from the result of this study, where it was observed that FS and ATTSD did not differ between groups. These variables did not present correlations with $\mathrm{FE}$ and DWG.

Reviewing the literature on the digestion of starch in beef cattle, it was observed the existence of differences in starch digestion among individuals, suggesting that genetic components influence these differences, but that the mechanisms behind them are still unknown and are probably related to factors inherent to the ingestion, fermentation, digestion, and tamponade of the gastrointestinal tract. Channon and Rowe (2003) commented that Bos taurus cattle digest more starch than Bos indicus animals, probably due to the adaptation of
Bos taurus animals over time to diets with high amounts of starch, concluding that fecal starch is a good way to identify differences between animals. Channon et al. (2004) in their experiment on the influence of genetics on starch digestion, found that starch digestion in the total digestive tract may be related to individual genetic factors and that these differences may contribute to differences between animals in feed use and feed efficiency.

Biological markers are important for a better understanding of the physiological basis associated with FE and that there is a need for further studies to understand the metabolism involved in this efficiency, as well as to discover new biological markers for FE (Montanholi, 2006).

The discriminant function found presented $100 \%$ correct classification $(\mathrm{P}=0.17)$, which did not incorporate the starch data into its structure, being composed of the variables erythrocyte, hemoglobin, hematocrit, glucose, leukocyte, albumin, cholesterol, and urea, the last two variables being the ones with the highest weight in the discrimination of the groups. Based on the selected discriminant model, the classification equations calculated for the animals of HE and LE were:

$\mathrm{HE}=-361.46-(19.756 \mathrm{x}$ erythrocyte $)-(52.655 \mathrm{x}$ hemoglobin $)+(14.552 \times$ hematocrit $)+(3.6 \mathrm{x}$ glucose $)+(16.746 \times$ leukocyte $)+(94.52 \times$ albumin $)+(2.591 \times$ cholesterol $)+(0.087 \times$ urea $)$; $\mathrm{LE}=-327.848-(20.188 \mathrm{x}$ erythrocyte $)-(51.798$ $\mathrm{x}$ hemoglobin $)+(15.91 \mathrm{x}$ hematocrit $)+(3.036 \mathrm{x}$ glucose $)+(15.24 \times$ leukocyte $)+(82.711 \mathrm{x}$ albumin $)+(2.545 \times$ cholesterol $)+(0.611 \times$ urea $)$.

The discriminating function model found was able to correctly classify the animals according to their biological efficiency, but not with an adequate level of statistical significance.

The profitability of the system was evaluated for the two groups of animals, $\mathrm{HE}$ and LE, considering the data on feed intake, DWG, FE, and food cost (not considering for this calculation other costs, besides feeding), and it was found that the HE group was more profitable than the LE (Table 4). 
These results confirm the statement that it is not all animals that have appropriate characteristics to be fed profitably in the feedlot system. In the simulation performed for the period time commonly used in the country's feedlot (average of 90 days), the animals of HE presented a surplus of $\mathrm{R} \$ 155.42$ concerning those of LE.

Table 4. Economic evaluation and simulation according to the performance of the high groups and low feed efficiency of beef cattle in the feedlot

\begin{tabular}{|c|c|c|}
\hline Indexes & $\mathrm{HE}$ & $\mathrm{LE}$ \\
\hline Food cost (R $\$ /$ day $)$ & 8.51 & 7.90 \\
\hline Revenue (R\$/kg BW) & 5.25 & 5.25 \\
\hline DWG $(\mathrm{kg})$ & 1.92 & 1.48 \\
\hline Gross profit ( $\mathrm{R} \$ /$ day) & 1.58 & -0.15 \\
\hline Gross profit ( $\mathrm{R} \$ / 42$ days) & 66.25 & -6.28 \\
\hline Surplus HE x LE (R \$/42 days) & 72.53 & - \\
\hline Surplus HE x LE (R $\$ / 90$ days - estimate) & 155.42 & - \\
\hline
\end{tabular}

BW: Body weight; DWG: Daily weight gain; HE: High feed efficiency; LE: Low feed efficiency.

Thus, methodologies that can identify animals with better nutritional efficiency before they enter the fattening phase can become decision-making tools. This will help breeders to allocate animals of high nutritional efficiency to the feedlot system and those of low nutritional efficiency to the pasture fattening system, optimizing feed costs.

The present study found differences between the animals evaluated, being possible to divide them into two distinct groups concerning feed efficiency, HE and LE. The statistical data of the discriminant analysis generated a model that provided a correct classification of $100 \%$ $(\mathrm{P}=0.17)$ of the animals with different FE. However, it was not possible to affirm with total assertiveness that the variables BM, ATTSD, and FS can be used as indicators of FE of beef cattle in the feedlot, under the conditions of the study in question.

\section{REFERENCES}

ALMEIDA, R. Consumo e eficiência alimentar de bovinos em crescimento. 2005. 181f. Tese (Doutorado em Agronomia) - Escola Superior de Agricultura Luiz de Queiroz, Universidade de São Paulo, Piracicaba, SP.

BASARAB, J.A.; PRICE, M.A.; AALHUS, J.L. et al. Residual feed intake and body composition in young growing cattle. Can. J. Anim. Sci., v.83, p.189-204, 2003.
BOURGON, S.L.; AMORIMB, M.D.; MILLERC, S.P. et al. Associations of blood parameters with age, feed efficiency and sampling routine in young beef bulls. Livest. Sci., v.195, p.27-37, 2017 .

CAETANO, M. Estudo das perdas de amido em confinamentos brasileiros e do uso do amido fecal como ferramenta de manejo de bovinos confinados. 2008. 76f. Dissertação (Mestrado em Agronomia) - Escola Superior de Agricultura Luiz de Queiroz, Universidade de São Paulo, Piracicaba, SP.

CHANNON, A.F.; ROWE, J.B. Beefing up starch digestion. Recent Adv. Anim. Nutrit. Aust., v.14, p.197-206, 2003.

CHANNON, A.F.; ROWE, J.B.; HERD, R.M. Genetic variation in starch digestion in feedlot cattle and its association with residual feed intake. Aust. J. Exp. Agric., v.44, p.469-474, 2004.

CLEMMONS, B.A.; MIHELIC, R.I.; BECKFORD, R.C. et al. Serum metabolites associated with feed efficiency in black angus steers. Metabolomics, v.13, p.1-8, 2017.

CORONA, L.; OWENS, F.N.; ZINN, R.A. Impact of corn vitreousness and processing on site and extent of digestion by feedlot cattle. J. Anim. Sci., v.84, p.3020-3031, 2006.

EUCLIDES FILHO, K.; EUCLIDES, V.P.B.; FIGUEIREDO, G.R. et al. Eficiência bionutricional de animais Nelore e seus mestiços com Simental e Aberdeen Angus, em duas dietas. Rev. Bras. Zootec., v.30, p.77-82, 2001. 
EUCLIDES FILHO, K.; FIGUEIREDO, G.R.; EUCLIDES, V.P.B. et al. Desempenho de diferentes grupos genéticos de bovinos de corte em confinamento. Rev. Bras. Zootec., v.32, p.1114-1122, 2003.

FERNANDES, S.R.; STIEVEN, I.C.B.; ZANETTI, G.F. et al. Características de desempenho e eficiência alimentar de touros Purunã em crescimento de três classes de consumo alimentar residual. Arq. Bras. Med. Vet. Zootec., v.66, p.268-276, 2014.

FERREIRA, I.C., SILVA, M.A., BARBOSA, F.A. et al. Avaliação técnica e econômica de diferentes grupos genéticos de bovinos de corte machos superprecoces e do sistema de produção em confinamento. Arq. Bras. Med. Vet. Zootec., v.61, p.243-250, 2009.

HAMMOND, A.C. Update on BUN and MUN as a guide for protein supplementation in cattle. In: ANNUAL RUMINANT NUTRITION SYMPOSIUM, 3., 1992, Florida. Proceedings... Florida: [s.n.], 1992. p.34601-34672.

HERD, R.M.; ODDY, V.H.; RICHARDSON, E.C. Biological basis for variation in residual feed intake in beef cattle. 1. Review of potential mechanisms. Aust. J. Exp. Agric., v.44, p.423430, 2004.

LOPES, M.A.; MAGALHÃES, G.P. Análise da rentabilidade da terminação de bovinos de corte em condições de confinamento: um estudo de caso. Arq. Bras. Med. Vet. Zootec., v.57, p.374379, 2005.

MONTANHOLI, Y.R. Genetic improvement in beef cattle for feed efficiency: increasing our understanding of the biological basis. In: BEEF IMPROVEMENT FEDERATION: RESEARCH, SYMPOSIUM \& CONVENTION, 2006, Manhattan. Proceedings... Manhattan: [s.n.] 2006. Available in: http://www.bifconference.com/bif2007/Symposi um/110_Genetic_Improvement.pdf. Accessed in: 19 May 2018.

MONTANHOLI, Y.R.; HAAS, L.S.; SWANSON, K.C. et al. Liver morphometrics and metabolic blood profile across divergent phenotypes for feed efficiency in the bovine. Acta Vet. Scand., v.59, p.24, 2017.
NUTRIENT requirements of beef cattle. 7. ed. rev. update. Washington: National Academies Press., 2000. 381p.

RICHARDSON, E.C.; HERD, R.M.; COLDITZ, I.G. et al. Red cell profiles of Angus steers selected for and against residual feed intake. Asian Australas. J. Anim. Sci., v.13, Suppl.1, p.195, 2000.

SANTANA, M.H.A.; OLIVEIRA JUNIOR, G.A.; GOMES, R.C. et al. Genetic parameter estimates for feed efficiency and dry matter intake and their association with growth and carcass traits in Nellore cattle. Livest. Sci., v.167, p.80-85, 2014.

SILVA, H.L.; FRANÇA, A.F.S.; FERREIRA, F.G.C. et al. Indicadores fecais de bovinos nelore alimentados com dietas de alta proporção de concentrado. Ciênc. Anim. Bras., v.13, p.145-156, 2012.

STELLA, T.R. Desempenho, característica de carcaça e parâmetros fecais indicativos da digestão do amido e suas relações com a eficiência alimentar de bovinos Nelore. 2010. 63f. Dissertação (Mestrado em Zootecnia) - Faculdade de Zootecnia e Engenharia de Alimentos, Universidade de São Paulo, Pirassununga, SP.

STIEVEN, I.C.B. Relações do consumo alimentar residual com perfil hematológico, estresse $e$ comportamento ingestivo em bovinos Purunã. 2012. 66f. Dissertação (Mestrado em Ciências Veterinárias) - Ciências Agrárias, Universidade Federal do Paraná, Curitiba, PR.

YOUNG, J.W. Gluconeogenesis in cattle: significance and methodology. J. Dairy Sci., v.60, p.1-15, 1977.

ZINN, R.A.; BARRERAS, A.; CORONA, L. et al. Starch digestion by feedlot cattle: Predictions from analysis of feed and fecal starch and nitrogen. J. Anim. Sci., v.85, p.1727-1730, 2007. 